\title{
THE WAGES OF DESTRUCTION: THE MAKING AND BREAKING OF THE NAZI ECONOMY
}

\section{Adam Tooze}

London: Penguin Books, 2007

$800+$ xxvii pages

Index, list of illustrations, tables and photos

ISBN: 978-0-141-00348-1 (Paperback)

R90-00-R140-00 depending on the South African outlet (internet acquisition, usually more expensive than other outlets, excluded here)

When can a country go to war, if ever? Tooze does not answer this question in general. He focuses on the economy of pre-war Germany and the years to follow under Nazi rule. A tour de force in political economy with a focus on one case study, it is worth consulting.

Tooze demonstrates that, despite stereotypes and the frequent hype about the sophisticated and nearly unbeatable Nazi war machine, Germany was far from ready to go to war. As a matter of fact, it was not - and it was unlikely to be ever in such a position, given the then international balance of power and global economic tendencies. Economists, politicians and military leaders within Germany argued before the time that it was more than a risk to go to war - doing so bordered on folly.

Tooze deploys a meticulous analysis of the state of the German economy since the end of the First World War, the Weimar Republic and the perceived impressive rise of the German economy under the Nazis. Archival research is splendid, candid and exhaustive.

The work is a study of how a political leadership influenced by a few power hungry can fall into the trap of groupthink and ignore important economic indicators and resource realities. It is a telling story of how political leadership bent

Scientia Militaria, South African Journal of Military Studies,

Vol 39, Nr 1, 2011, pp. 140-142. doi: $10.5787 / 39-1-107$ on attaining their own vision can ignore - if not vilify - their (economic) advisors. Ideology and a focus on segmental interests can be as blinding as a burning sun, it seems. 
Some detailed examples are the extent to which Germany was dependent on foreign loans to kick-start its post World War I economy and enhance growth. Tooze reflects in his study on the co-existence of rural poverty with economic growth - even while the economy expanded through militarisation and an increasing tax burden on German citizens under Hitler and cohorts (by the way, not the first time in German history). The dependence by the German economy on scarce resources, which could only be made up by costly military ventures, is another. The inversion of logic by those striving for more space or territory - the so-called lebensraum - that an extension of territory would necessarily lead to increased capital accumulation and its outcomes is worth studying.

The unintended consequences of the social engineered use of slave labour makes for harrowing reading in human terms. However, history and economy can react in unforeseen ways in the real life of human materialism. Solving the labour problem through slave labour became an extremely costly exercise that countered any logic of a human society or a carefully controlled/managed economy such as in a social democratic state. Tooze amply demonstrates how supreme coercion in itself became expensive - an inverted Midas hand of gold to dust and ashes ... so different from what was envisaged in the grand plan based on what the master-leaders saw as supreme realism backed up by efficient technocratic administration.

Numerous examples backed up by economic theory and monetary data are shared with the reader. It is virtually impossible to relate all here even if in broad strokes. The fundamental misunderstanding of human productivity and what we would call ,human capital' today is one. The lack of keeping an ear and eye open to economic planners, production specialists and even socially informed military leaders is another (perhaps it is useful to mention here that ,open eyes and ears' is not to be confused with secret services and military intelligence. In fact, the latter could contribute to being misinformed).

The increasing denialism of a political leadership steeped in what they saw as the ,current reality' is another. Ironically, the Nazi experience is one of ,hard realism proven wrong'. Despite concrete evidence about the "progress" of arms production and increased "sophistication", Tooze demonstrates that this "upward productivity curve" translated into economic decline and eventual total socioeconomic exhaustion. Political leaders confined to thinking within their own restricted circles invited disaster and a growing socio-economic implosion quite evident to other observers then and now.

Tooze points out that German arms production and the quality of their arms, even if better than those of other contemporaries, was by far not as superior as perceived by the political leadership. The author supplies dozens of examples where the military adversaries of Nazi Germany had better hardware at the start of the war 
- and learned faster from their mistakes. The disadvantage of German adversaries at the start of the war was frequently not the quality of the material but the application of it. The adversaries learned from it and corrected their mistakes speedily.

This work begs further research on other historical and contemporary case studies. Tooze's conclusions suggest comparative studies relating to (inter)national political economy in interface with militarisation and the one-sided projection of power through uncritical advocacy of (an) ideology - even if rationalised by terms such as "current reality".

The book cannot be ignored for its depth, the linkage between economic precariousness, misguided elite visions and political failure. It should not be read as ,pure history' or just an extensive time-bounded international political economy essay. It holds value for other countries and states that believe they have strong economies and therefore can project military power outwards in the belief that the world will change according to their projections.

The intricate balance between economic management and growth guided by political and social realist-idealism were replaced by opportunism and power in the case of Nazi Germany - not that these delusions were wiped away after World War II and the fall of Fascism and Nazism. Available economic data and geographical realities were manipulated to exclude economic sensibility at the time. Tooze holds a reservoir of lessons learnt that are grounded in real life and provides pointers for the future on the globe. Whether others in our time will take heed, is another question.

Ian Liebenberg, Centre for Military Studies (CEMIS), Faculty of Military Science, University of Stellenbosch 